\title{
BETWEEN INDIGENISM AND MESTIZAJE (MISCEGENATION): INTERPRETATIONS ABOUT THE COLONIAL IN THE PROSE OF GABRIELA MISTRAL ${ }^{1}$
}

\author{
Entre el Indigenismo y el mestizaje: lecturas sobre lo colonial \\ en la prosa de Gabriela Mistral \\ Daniela Schröder*
}

\begin{abstract}
This article reflects on Gabriela Mistral's interpretations of the colonial period in her written prose. The hypothesis presented is that these historical re-interpretations were a crucial part in the reformulation of the discourse concerning American identity that took place in the early decades of the twentieth century, and in which Mistral was a key figure. The first
\end{abstract}

\footnotetext{
${ }^{1}$ Este artículo fue enviado a revisión inicialmente en español y ha sido traducido al inglés gracias al Proyecto FP150008, "Aumento y mejora del índice de impacto y de la internacionalización de la revista Universum por medio de la publicación de un mayor número de artículos en inglés". Fondo de Publicación de Revistas Científicas 2015, Programa de Información Científica, Comisión Nacional de Investigación Científica y Tecnológica (Conicyt), Chile.
}

This paper was initially sent for review in Spanish, and it has been translated into English with the support of the Project FP150008, "Aumento y mejora del índice de impacto y de la internacionalización de la revista Universum por medio de la publicación de un mayor número de artículos en inglés." Fund for publication of Scientific Journals 2015, Scientific Information Program, Scientific and Technological Research National Commission (Conicyt), Chile.

This article is the product of the beginnings of the investigation for my Masters in Latin American Studies thesis for the Universidad of Chile.

* Estudiante del Programa de Magíster en Estudios Latinoamericanos, Universidad de Chile. Santiago, Chile. Correo electrónico: danielaschb@gmail.com

Artículo recibido el 06 de enero de 2016. Artículo aceptado el 06 de junio de 2016. 
two sections analyze the images she constructs of the colonial period and independence, contrasting them with the conventions established by nineteenth century historiography. The last section discusses Mistral's position in the cultural field of the time, highlighting the tensions found in her own work between americanismo, Indigenism and discussions concerning mestizaje (miscegenation).

Keywords: Gabriela Mistral, colonial period, americanismo, Indigenism, mestizaje.

\section{RESUMEN}

El presente artículo reflexiona en torno a la lectura sobre la Colonia y lo colonial que desarrolla Gabriela Mistral en sus escritos en prosa. La hipótesis que se sostiene es que esta relectura histórica fue fundamental para el proceso de reformulación de los discursos sobre la identidad americana en las primeras décadas del siglo XX, en el que Mistral fue una figura clave. Los dos primeros apartados analizan las imágenes construidas de la Colonia y la Independencia, contrastándolas con las convenciones establecidas por la historiografía del XIX. El último apartado pretende discutir su posicionamiento en el campo cultural de la época, para que lo cual se relevan las tensiones que en su misma obra se verifican entre el americanismo, el Indigenismo y los discursos en torno al mestizaje.

Palabras clave: Gabriela Mistral, Colonia, Americanismo, Indigenismo, mestizaje.

Again we are who we were,

Tape men, walking ring, old droves, long habit straight into the base, where the mother was augur which for four centuries flame, night throughout the Andes and the cry is launched.

(Cordillera. Gabriela Mistral)

The first decades of the 20th century in Latin America marked a historical break between the oligarchic developmental model and the creation of a new horizon of modernization, more bourgeois, that has been named a popularnational (Tourine). This transformation had its revolutionary expression in Mexico, while the majority of the remaining countries had more turbulent transitions, but less violent and radical, because the oligarchic power kept its hegemony in agriculture far after the beginning of the century. The process was accompanied by a transformation of critical thinking and social imaginaries about the country 
and America. The transformation from a colonial system known for the ideal of social segregation towards a system that sought integration and democratization (although with significant contradictions in practice), implied the elaboration of new political and cultural projects that would require re-interpreting history.

A general hypothesis that I use here is that the colonial period, that was disregarded to a second or third level by the historiography of the XIX century, started to be a topic; it started to be a topic of a renewed interest for the purpose of reformulating the American identity. Within the discursive framework, there are several diverse forms of americanismo ${ }^{2}$, Hispanism and Indigenism highlighted as main themes. Without a doubt, figures such as Pedro Henríquez Ureña, José Carlos Mariátegui, Teresa de la Parra or the Brazilian trio formed by Gilberto Freyre, Sérgio Buarque de Holanda and Caio Prado Júnior, set the guidelines for a historical re-interpretation that not only had another look and other questions for the colonial period, but also ignited questioning about its contemporary obstinate persistence in social problems and in our social and artistic imaginaries. However, the ideology that turned out to be more efficient and durable for restructuring the modern national and continental identity was mestizaje, a concept coined by José Vasconcelos in the context of the Mexican Revolution, and that "presupposed the disappearance of the two notions that originated it: Indigenism and Criollism" (Zermeño, 2001: 287).

It appears to me that the figure of Gabriela Mistral is fundamental in the process of reformulating continental identity, and in her work one can observe the tensions that cross the cultural field of her time. These tensions can be verified by observing the diverse names that she refers to, what today we call "Latin America": Spanish America, Hispanic America, Latin America, Our America, Mestiza America or Indoamérica ${ }^{3}$; most of them were formed in her time, but are expressions of very different interpretations about our history and identity (Rojo, 2001: 7). Already canonized as a poet, she still needs to be recognized as an author that positioned herself in front of contingent political, social and cultural matters, as well as the history of Latin America. In a text in which she reflects about the archaeological excavations that foreigners were doing in Peru and Mexico, she says:

\footnotetext{
${ }^{2}$ Even though its use in the period was not unique, the term was used to refer to American unity, usually excluding the United States of America from a anti-imperialist position. We have preferred to leave the concept in Spanish so that there is no confusion that can be generated by the terms "americanism" (that only refers to the U.S.) and "pan-Americanism" (that involves the rest of the continent, but was what the U.S. used to ideologically spread its influence in the region).

${ }^{3}$ Latinoamérica, América española, Hispanoamérica, América Latina, América nuestra, América mestiza o Indoamérica.
} 
We have allowed strangers, first, because of our poverty for the labor of large research; but we should not let them interpret that material, that is almost a manipulation with the members of our soul (Nuestra América 23-24) ${ }^{4}$.

What is interesting to me about this quote is the awareness that it shows about the political implications that the interpretation of the past has and about the exercise of power it means that "another" gives a voice to those findings that are "inherent" of Latin America; this is what Jean Franco calls the "fight for interpretative power". In this case, the identities that Mistral puts into play are those of a Latin American individual who would make those treasures of the indigenous past talk ("the frescos of the Mayan and Quechuan cultures"), because they belong to him as a mestizo. The problem that is involved in an operation like this is one of the complexities that I intend to address here.

In this paper I will stop to analyze the role that Mistral gives to the colonial period in the frame of her historical reinterpretation, taking a selection of her texts in prose as an object of the analysis. It is precisely her extensive work in prose that has been most neglected by the critics ${ }^{5}$, in part because several of her texts still remain unpublished. This is why the approach that I propose might be tentative and insufficient, among other things, because it cannot take into consideration the overview that is essential for a complete interpretation ${ }^{6}$.

The analysis that continues is organized in the following way: the first two sections are about the texts where Mistral portrayed certain figures of the colonial times and the Independence, respectively. I stop to analyze who those characters were, the features that stand out in them, and the textual resources that she uses (taking into account that it is not an approach from the historical discipline) to relate her interest with her own productive environment. In general terms, I wonder what image or images were created about the colonial world and the Independence, contrasting it with the established conventions by the historiography of the XIX century. In the last section I will try to position Mistral in the discursive field of her time, with the intention of discussing the relevance of naming her social thinking as indigenist and pointing out the need to relate it to the "ideology of mestizaje" (Zermeño, 2011).

\footnotetext{
${ }^{4}$ The citations of Gabriela Mistral's text will be referenced with the title of the book that they were published in (sometimes abbreviated), so that there is no confusion with her authorship and that of the editors. The citations of critical texts will have the last name of the author as usual.

${ }^{5}$ As Pedro Barcia pointed out in his study, Mistral developed intense journalist work for over fifty years (between 1904-1957), and to this, one has to add all the texts that reproduced her multiple conferences and speeches in diverse contexts.

${ }^{6}$ Add in some point of the last section. I critique other works for not taking into account the contradictions of Mistral's discourse, but mine can also err of the same, because her work is so large that a collective work of criticism is needed.
} 


\section{FIGURES OF THE COLONIAL}

To our knowledge, there are three characters from the colonial period that Gabriela Mistral wrote about: Sister Juana Inés de la Cruz, Fray Bartolomé de las Casas and Sir Vasco de Quiroga. The last two interested her as exceptional figures that represent the defense of the indigenous in the colonial context. In the article about Fray Bartolomé, she makes reference to the historian Carlos Pereyra; according to him there were other Spanish missionaries that were valued equally or more so than Las Casas: Motolinia, Pedro de Gante, Luis de Valdivia and especially, Vasco de Quiroga. All of them defended the "indiada" (indigenous people), as referred to by Mistral, but "That being true, it turns out, however, that for the people, as well as the Mexican intellectuals, Fray Bartolomé still represents the quintessential missionary, a passionate missionary coming from upright Christianity" (Croquis... 143). For her, Las Casas was the maximum representative of missions, which in her judgment were the most valuable experiences of colonial America:

The historical work of Spanish missions visibly grows in the Continent and covers the historical horizon: there is no other, not the great seafarers nor the great explorers that can take its brilliant prestige (143).

Mistral does not dedicate articles to any military figure, explorer, seafarer, viceroy or any other government authority. Instead, she is interested by Bartolomé de Las Casas and Vasco de Quiroga, who were a sort of popular saint. Here, the benchmark for the profiles she constructs of them is not as heroes but as saints. In regards to Vasco de Quiroga, she points out that the indigenous people of Michoacán still "say his name as the synonym for holiness" (Croquis.. 81), but to take into consideration the devotion that Las Casas generates, she proposes an imaginary scene in which his bones, transformed into relics by the canonization, come back to land of America. Mistral would suggest that the figure of Las Casas, who, although born in Spain, was native to America. She even assigns him a homeland: Mexico or Guatemala, "regions of solar heat and celibacy habits", where his bones would melt into the ground in which he gave his most sacred fruits. Fray Bartolomé, "the andariego" ("the restless") (like herself), "wandered for several tropical parallels carrying the Gospel, and more than carrying, threaded through the middle of his chest, rehearsing 'God's plan' in several regions" (144). In every other place his bones would be honored by the "great and still unhappy indigenous, and by the mestizaje the same" (145), in a true continental greeting.

In respect to Vasco de Quiroga, she points out that, like Fray Bartolomé, he did not come to prosper individually, but to show that "the Christian Spain, the one of Queen Isabella the Catholic, was true" (79). According to what we can 
see here, it seems that for Mistral the colonial project had a valuable part in the necessary diffusion of Christianity, but that it finished by declining and corrupting its Catholic postulates by violent subjection of the indigenous population. The figures of these two religious men represent the ideal of the evangelization project, who knew how to protect the indigenous instead of oppressing them.

In respect to the text dedicated to Sister Juana Inés de la Cruz, it was first published in El Mercurio (Santiago, Chile), and soon was included in the book Lecturas para mujeres (1923) (Readings for women) that the same Mistral edited in postrevolutionary Mexico. Considering the pedagogic spirit of the book and the biographical character of the text, we can infer that the poet conceived Sister Juana as an exemplary model of the Mexican woman. Even though the brevity of her texts create a discussion more about semblance than a biography -that in the historiography of XIX was a privileged genre, among other things, for its pedagogical capacity for popularizing an exemplary life (Colmenares, 2006: 82)the pedagogical intention should not be underestimated as a factor that influences the construction of images related to historical characters, considering that the texts are not destined to a well-educated public but one less specialized, a popular one. The same Mistral highlights her interest in "biographies without scholarship" since the "Plutarch genre" proves to be more educational (Aldinger, 2015: 2).

In accordance to what the text signaled as its intention, it looked to portray Sister Juana as a good Christian, strictly devoted to morality and interested in the intellectual path for becoming closer to God, shaking the mystic impression that hung over her figure. Mistral stops for a lengthily amount of time to describe her beautiful physical features, which she associates in parallel with her qualities and moral virtues: there is no sensuality or emotion in her eyes nor her mouth, but acute thinking, without signs of dreaming. Even though she is of Spanish blood, and does not have a way to take ownership through that path, it is stated that she was born in between two volcanoes in American land, in a scene whose light and clarity would be expressed in her features and virtues. As we can see, like the majority of the historical figures that are portrayed, Mistral worries about presenting Sister Juana as an American one.

According to what Julio Aldinger pointed out, Mistral's text was constructed using as a base Juana de Asbaje de Amado Nervo and three portraits, whose reproductions were included in that book (3). Following that structure, but simplifying it, Mistral reveals that within in the nun's biography the most important moment of them all is the ending:

And she wants even more: she seeks the sackcloth; she knows the feeling of blood on her tormented waist. This is for me the most beautiful hour of her life; without it I would not love her [...] Miraculous girl that played at the foot of the volcanoes 
in the gardens of Neplanta; almost fabulous the sharp young women of the vice royal court; admirable the educated nun, but great over all, the nun that is freed of intellectual vanity, forgets the fame and lyrics, and in the face of the sick ones she gathers the blow of death (Croquis ... 87).

Although certain features are highlighted like the a critical and ironic sense that are shared with Saint Teresa ("characteristics of her race"), the image of Sister Juana that offers for posterity and with which she has a more intimate connection, is that of the religious woman de-attached from her intellectual endeavors and not only involved in humble work, but in the painful experience of martyrdom. That is her "perfect hour", waiting for death. Beyond highlighting her as an American figure, it does not appear to have here a redemption for the purpose of reflecting about the colonial, but more about a relationship to the identity that is considered to correspond to the feminine gender, an ambivalent identity: Sister Juana is the nun surrendered to martyrdom, but she is also the icon of an intellectual woman from the New Spain.

\section{THE FIGURES OF INDEPENDENCE}

In the Mistral's texts about Independence and its highlighted figures, a reformulation of the established conventions by the historiography of the XIX century is appreciated, which at the beginning of the new century would continue to be hegemonic. According to Germán Colmenares, in his desire to elaborate a solid national identity, the historians of the era (historians by practice, not professionals), established the Independence as a moment of radical historical break: the colonial time was defined as a closed period, and the promising future of the young republicans were seen as foreshadows of the heroic image of the liberators. This vision, that represented "the solution at an ideological level, of profound cultural conflicts" (19), had to be reformulated according to the transformations of the new century, even though its deeps roots would continue manifesting itself throughout Mistral's prose even up to our days.

One of the fundamental transformations related to this particular work of Mistral is that the "imagined community" (in the words of Benedict Anderson) that calls her attention is mainly the one of America, instead of the national stories that kept the historiography of the past century busy. This would imply that she would have to operate certain transformations in the inherited conventions, but there are others that would keep demonstrating their ideological efficacy and pedagogical power. The centrality of the hero figure is one of the characteristics that would remain, but changing, as we will see, the choice of figures and the focus of their representations. 
Simón Bolívar will be the liberation hero that Mistral will keep in the preeminent place that was set for him by the historiography of the XIX century. There are two brief texts that she would dedicate to him. I will stop in the first of them, which is structured around his "face like a forty-year-old" (Escritos politicos 196). Following the distinctive character of the descriptions with which the historiographers verbally described the heroes, Mistral would review the features of the very particular Bolívar, a mature man to whom his wrinkles "make him a prisoner's fence, and the prison is true and corresponds to the fatigue and the disappointment that finally reached him" (196). The image that she portrays is not about a Bolívar proud of his own achievements, who would talk about a glorious future, it is the figure of a great hero, but disappointed in his American compatriots.

His nose is the one of the most aquiline among the several that can be tracked in the "indo-Spanish iconography", and because they say that this feature is very valuable, the "knife thinness" and "without the pressure to fatten" of his nose talks about "the leading edge of his will". This means, among the priest Hidalgo, Sucre, San Martín, Portales and Alberdi, whom are the figures she mentions in regards to this facial feature, Bolívar is the one that personifies the most energetic will. His forehead, that because it is so big, unbalances his head, is a "type of cleaved plain, of working fields with a visible plow field that just went by" (197). There are visible marks of his arduous work, and the "sad things" that he has lived: the disloyalty of Páez, the anarchy in Peru, and the worst are the ones that he has received after:

This forehead looks towards the South American land to see if it has been divided, and there it is, still in provinces, only with its idle mestizo owner of the indigenous harvest; he puts back his forehead to look in the distance, and what he sees are the frontiers that he did not want and that every day are more set and straight; sometimes, this forehead with intrusive eyes falls upon us, to see what we are, and finds us jealous like Paez, betrayers like the bad black Jamaican, and above all, weak from the tropics that never displaced him (197).

It's the image of a powerful Bolívar that is not only the hero of the past, but the judge of the political future of the continent and the ethics of its inhabitants. Ultimately, he is an effigy that is called to rectify the courses that American history has taken. Mistral brings his figure to the present to articulate her own americanismo in continuation with Bolivian ideology.

The text continues with the description of his body, which was small in real life. Even she admits that would have liked him to be much larger, she says that even this she praises, because she considers this a sign of "loyalty to race" (198), because that is what "our indigenous-Spanish" is. Thus, we can see that, 
even though he is "white" -as pointed out in "Sentido del 12 de Octubre"- she is interested in identifying him with the American men, which for her is excellently represented by the mestizos. To emphasize the "South Americanism" of Bolívar, she also points out that this was expressed in his practicality for so many things: "for so many chores we serve, by carrying the strength of a second and third blood and we are not a stiff race nor of a single pedal" (199).

Besides, she stays away from the monumental image built in the XIX century to highlight his human side: "the intimidating mount did not turn him" (198), and moreover: "Let us make him a creature of daily life instead of the anniversary men, let us live him in the permanence and not only in the slow stitches of the centenarians" (199). In another text, in the one that she defends him against the critics of his ambition, she calls the attention on him as a man that ate and dressed in clothes as it is natural (200). Mistral signifies the figure of Bolívar as a heroic representative, but always a human of the American mestizo race, whose example should live in us: "Let us live him in continuity as we live the law; let us keep him as our landscape, until it runs in our blood, transformed into our blood" (199).

Another one of the figures that she elevates to the highest level of the American race is Jose Martí, who she puts on the same level as Bolívar and José Vasconcelos7. About Martí, however, she says is "the American master most conspicuous in my work" (Escritos politicos 214). To place his character, she compares him with the most diverse and famous men: "To Marco Aurelio, Carlo Magno, some popes, San Luis, Alfondo el Sabio, Eliseo Reclus or Michelet" that they call "a friend of man", and also José Martí. Martí is a "saint of struggle", a "fighter without hate", that turns out to be more pure than Homer and more of a pacifist than Gandhi. Even though he is positioned at a worldly level, elbow to elbow with the big names of Europe, she additionally worries about situating him well among the American domain. When asked how it was possible that a man as virtuous as him was born, the answer is in race and geography. The masculinity comes from "the explorer and Spanish conqueror, the leather belt of history, master champion whose resistance still astonishes the chronicler that tells us about his actions" (212), while the affectionate "comes from the earth and the Antillean environment, where Spanish leather became softer to leave a sweeter and more pleasant race than the one that arrived." Signaling that even the Antillean Indian, the most benevolent out of all the Americans, along with the "Quechua Aymará", were wiped out, their virtues probably transubstantiated into the earth and that has influence over the living. Ultimately, Martí is -if not for his race but for his

\footnotetext{
${ }^{7}$ About the influence of the work of Vasconcelos and the tight relationship that they established in the educational work in the Mexican Revolution, we will discuss in the following section, but we have to note here the privileged place in which she puts him.
} 
virtues that were absorbed by the Antillean earth- a mestizo that brings the best of both races. In his political actions and in his literary language, Martí is the only loyal son from the tropics, the land of abundance without penalties in contrast to what the retractors of tropicalismo say.

Like Bolívar, she branded him as a representative and guide to the American race that he himself is a product of: "[the] guide of men terribly pure that America produced in him" (214). Reflecting explicitly about his own gesture, she says:

In these painful uprisings to the American situation [...] we bring our Bolívar back from so far, so that he can support the confidence in our intelligence, and from a shorter distance in the time we bring back our José Martí so that he can wash us with his white bleach, the marks of our people, the prolonged impurity and persistence of their comforts and deals (215).

They are heroes incarnated, whose human remembrance (even though she eventually describes Martí as "supernatural") gives confidence to the race and its potential in historic trances like those from the 30 s.

To the forgotten figure of Eugenio María de Hostos, she also dedicates a text, in which I will refer to briefly. To the Puerto Rican, she presents him as a precedent to contemporary americanismo: "Before us, we believe to have invented continentalism, as a nationality, Hostos experienced this with his country's progression and he served it with full hands" (226) She especially highlights his cultural and pedagogical work -although she explains her differences in respect to some points, like his affiliation with positivism- and puts him on a par with Sarmiento and Bello. Mistral points out that "The Colony stank at these points in time," and even though he could, Hostos refused to live under the protection of those old institutions. Instead, "he clearly saw that the political independence of the southern countries would remain unripe or could rot on the branch if great popular instructional efforts did not start right away". Hostos had been a "civilizer" like Sarmiento was ${ }^{8}$, and at the same time he accomplished the role to which he was encouraged during his time: the "heroic example" of fighting for the independence of his country.

It appears significant to me that these texts that Mistral dedicates to historical figures creates an image of the Independence that does not correspond to what was noted by the historiography of XIX, which was an event that marked a radical rupture between the colonial and the Republic. In theses texts, the Independence appears with temporariness, much more lax and deferred -perhaps

\footnotetext{
${ }^{8}$ It stands out, as Barcia (XCI) points out well, that Mistral praises Sarmiento in this and other texts, and there is never a moment where a critic slips about his crude racist and colonial vision.
} 
without looking for it- the rigid hegemonic chronology, which in the cases that consider the Caribbean, Cuba and Puerto Rico, the colonial period temporarily superimposes the Republic. Additionally, in the text "Conversando sobre la tierra" (Talking about the land), Mistral would prove to be very critical in front of the true social impact of the Independence. A lot of consideration surrounds us, an act of independence that truly freed a tenth of the population; we grant much dignity to a Constitution that calls us free in every way and that has thrown us over a feather pillow of confidence, from which we have not lifted our head to realize if we continue being free; many odes and many choirs we lift around our political heroes (cit. in Escritos políticos 14).

For Mistral, the Independence did not really free women nor peasants, and much less the indigenous, to whom the Republic subjected to much more violence for what the same colonies did, as she points out.

Like we previously mentioned, the treatment she gives to these heroes stands out, portraying them with an emphasis on their human dimension, looking to bring them closer to the popular reader. In the early text "Menos cóndor más huemul" (1926) (Less condor and more huemul), Mistrals reflected over the symbols of the Chilean national crest, which can be extended to her concept about all of the heroic figures of America. In front of the strength that the condor represents is the buck's defense, it is the defense of "the sensibility of a race: fine senses, vigilant intelligence, grace" (Escritos politicos 40). Mistral proposes a reinterpretation of the national history under this forgotten symbol that links the feminine with peace, and that also has its own heroic dimension: "Some national heroes belong to what we would call the order of the condor; the buck has, in parallel, his own, and the moment is good for highlighting these" (41). Instead of just considering "the action results" of the heroes (Colmenares, 2006: 85), Mistral stops with another historic sensibility for imagining them and representing them under the order of the buck, "far from that patriotism of choirs and badges", as pointed out by Jaime Quezada (Escritos politicos 9).

The three figures highlighted here are appropriate representatives of the americanismo that Mistral professes, in which she has today a privileged position. But the point that seems to me more important to highlight is the appropriation of these figure for the identity of a mestizo America. Bolívar and Martí, maybe the two heroes that are most great and beloved in her eyes, appear in her texts as mestizos. Their faces, bodies, virtues and abilities talk about "our race": the one of the "indigenous-Spanish", the "mestiza". In the following section we will see how Mistral's way of thinking converses with the indigenist, Hispanist and mestizaje contemporary discourse. 


\section{BETWEEN INDIGENISM AND MESTIZAJE}

The critical studies that have wondered about the social thinking of Mistral have tended to form an image that insists in her radicalism in several different areas, which among them highlights her indigenist position. However, I wonder if these interpretations do not respond more to our contemporary expectations than to a critical pursuit that allows the signs of her time to be seen in her work. Jaime Quezada, Jaime Concha, as wells as Figueroa, Silva and Vargas -authors of the book Tierra, indio, mujer. El pensamiento social de Gabriela Mistral (Land, indigenous, women. The social thinking of Gabriela Mistral)- characterize her way of thinking as indigenist and points out that this was strengthened after her stay in Mexico, where she participated in the educational reform promoted by José Vasconcelos, the then Minister of Education of the revolutionary government, and where she also met Haya de la Torre, a great representative of the aprist Peruvian Indigenism. Jaime Quezada -following Mistral in a press article of 1948 where she recognizes herself as a "forever indigenist"- clarifies that her first significant meeting with the indigenous was in 1919, in her exile to Magallanes, and after that she strengthened this commitment with her experience with the Mapuches -the "grey race"- in Temuco (Escritos politicos 12).

Besides the sensitive and keen reading that Jaime Concha presents in his book about Mistral, I disagree with the radical "anti-Hispanic" interpretation that he makes, in which he supports that Mistral had a completely negative vision about the Conquest. Without a doubt there are passages of her prose that would make him right, like when in the text "Musica Araucana" she refers to the Conquest as an "infernal machine" (Por la Humanidad... 132). Nonetheless, I think that this interpretation does not work to perceive the totality of the tension in her work. Let us see, for example, a fragment of the discourse that has been published entitled "Sentido del 12 de Octubre" (The meaning of October 12th):

The Spanish work in America shows many goods [...] in a poor discourse we have to say no more than its major grace, its supernatural charity, its acceptation of indigenous blood [...] This great national mercy and supernatural both from the Spanish, that embraces with resounding acceptance the indigenous race, it washes every one of their sins and floods with generosity in all of their faults (Nuestra América 20-21).

In my opinion, the critique does not consider the awkward declarations like the last one, the tension of the image that sorts out the complex social thinking of Mistral in regards to the concept of Indigenism, with no more clarifications. Pedro de Alba, in 1957, talked about Hispanism and the Indigenism of Mistral 
like there was no major contradictions. In the book of Figueroa, Silva and Vargas they talk indistinctly of the affiliation of Mistral to the discourse of mestizaje and Indigenism. Where can we position her today? I do not have interest in classifying her voice that, unique and original, resists those attempts, but I do think is relevant to make certain distinctions, supporting my opinion in the critique in the last decades has been compelled for the necessary task of asking about the ideological function of mestizaje discourse.

As pointed out by Guillermo Zermeño in his extensive study, the concept of mestizaje was transformed into the nucleus of an ideology that allowed for the articulation of an American identity apparently harmonic and with no contradictions for almost a century (311). The appearance of the term is linked to the Mexican Revolution, and is in debt to José Vasconcelos, who published in 1925 his book La raza cósmica (The cosmic race). Nonetheless, the critic highlights the long process in which this concept was brewing. Already starting in the XIX century, the term mestizo was releasing itself of its colonial meanings linked to the threat of social disintegration and moral degradation that was latent in the instability of the mixture, continuing to take the positive features that allowed it to make the figure of the mestizo representative of a national identity that wants to distance itself from the colonial past and project the modern future of a cohesive community (Zermeño, 2011:303-307). The ritual instauration of the "Feast of the race" was a key point in this process. The revolutionary Mexico changed the party of Hispanicity to celebrate in its place mestizaje, "the happy encounter between two cultures and the appearance of the third road or superior synthesis of the antagonism exerted between the indigenous and Spanish" (291). With this gesture mestizaje becomes an official ideology of Mexico, while the rest of Latin America was organizing itself rather in the intellectual and cultural field, in permanent tension with the Indigenism and the Criollism, two notions that the concept of mestizaje attempts to overcome under its synthetic formula (Zermeño, 2011:287).

It appears to me that the work of Mistral is a product but also an important contribution to that articulation process of the discussions around mestizaje at a continental level, considering the great circulation that her texts had, especially in Repertorio Americano. In the discussion mentioned above, which was specifically for the celebration of "Day of the Race", Mistral creates a very expressive image of its view of the American identity, in which the mestizo appears as an incarnated metaphor for the "reconciliation" between both races and cultures: a face "where the enemy factions accept assembling" in a "new body created between the Atlantic and the Pacific" (20). This image expresses the imaginary biologist and evolutionist that Mistral thinks of in the mestizaje in regards to the formation process of our specific continent. In a text that reflects on the racial question in light of genocide that was produced by Nazism, there would be virulent criticism of the dormant 
dangers in the racism that sleeps under the dead writing of the constitutions and religious creeds that speak of equality, but would reaffirm her interpretation of the uniqueness of Spanish America compared to the United States of America: it is a difference of "different races" (Por la Humanidad... 190). In its conception, the mestiza race would be composed of two equal quantitative and qualitative parts, which in her diverse texts and interventions Mistral would defend them that way. When in some texts she severely criticize the mestizo, is because they does not recognize or value their indigenous ancestry ${ }^{9}$, but it is the mestizaje that is in her proposal for the Americanist identity.

Anyway, the speech of Mistral is crossed by tensions that should be revised with much more detail than the one that I achieved here. The strong and persistent commitment of Mistral with the indigenous people is undeniable. It was expressed in her actions and political position: the demand of an agrarian reform that brings justice to the farmers and indigenous people of America has in Mistral one of the strongest and sharpest spokeswomen; likewise in her appreciation of the indigenous "literature" and folklore, and its own expressive and formal search, which would reach in Tala one of the crowning moments of Latin American literature.

As we have seen, the historic reinterpretation that Mistral makes comes back to the colonial to see the start of a conflict and a project: from one side, the oppression of the indigenous, and on the other, the start of a process of mixed races, that from the XX century can be read -around the new concept of mestizaje- as the origin of the unique identity of our America. Although in the colonial period began the brutal violence against the "indiada", that Mistral perceived in her time and that she reported every time it was needed, she redeems this period with the experience of the religious missions, especially for their educational role in the diffusion of Christianity and the Spanish language. The figures of Quiroga and Las Casas, to whom she portrays as guardians of the indigenous and mestizos, will turn into a fundamental reference in contemporary political fights. As for the Independence, we said that she elaborates a very different image of the one stated by the historiography of the XIX. In Mistral appears as a long breath, that portrayed at a continental level evidence its different times. A fundamental divergence in regards to the previous historiographic conventions, it is the treatment she gives to the heroes, to whom she portrays under the order of the buck, to use her own

\footnotetext{
${ }^{9}$ Refer to these two examples: "The creole mestizaje must be of the same or worst Iberian caste towards the maternal race [...] continued the annihilation of the indigenous with a felony that takes the surrounds of the perfect matricide" (Por la Humanidad... 134). "the moment will come in which the Latin American men will fully confess to their progenitors, things that up today they do reluctantly $[\ldots]$ he will confess his indigenous background with no blinded reluctance, finally, finally" (Nuestra América 24).
} 
expression. Nonetheless, more than the interest she shows in the human side of these heroes, it seems to me that she claims them mainly with a political objective, to show that their projects are still valid and unfinished, feeding from the history the new forms of americanismo that are being articulated in the new century.

It turns out relevant to consider that Mistral is redeeming all these historic figures as American figures, models that are an edifying example but also proof of the virtues that she associated with land and race. The author makes an effort to present them as mestizos, including those that are not: Sister Juana and Martí for example, those whose indigenous influence that had come through the land. As previously said, it seems that the concept of Indigenism falls short to realize the complex social thinking of Mistral, in which the concept of mestizaje occupies a central place. As stated by Zermeño and Cornejo Polar, it is about a concept that for about a century allowed for thinking in regards to Latin American identity as a project in which two races, experiences, history, languages, esthetic code, etc. join harmonically (Cornejo Polar, 1995: 2). Today we can see the problem that that notion resulted in, whose ideological function had served for naturalizing the persistence of the colonial opression that is verified in the material level as well as in the symbolic. As pointed out by Zermeño, the same indigenists at the beginning of the XX century were able to warn that the mestizo centrality implied a displacement of the indigenous figure as a political and cultural agent (285). It seems to me that the Indigenism of Mistral lays subordinated to the imaginary of mestizaje; however, in contrary of some facets of the mestizaje, she was one of the most relevant figures of her time in the fight to visualize and transform the life conditions of the indigenous and for valuing their culture. Considered inferior for her gender, today we should give her a place that corresponds to her in our cultural history.

\section{REFERENCES}

\section{Gabriela Mistral's Work}

Mistral, Gabriela. Croquis mexicanos. Santiago, Chile: Nascimento, 1979. Tala. Buenos Aires: Sur, 1938.

Quezada, Jaime (ed.). Gabriela Mistral. Escritos politicos. Santiago, Chile: FCE, 1994.

Gabriela Mistral. Nuestra América. Santiago, Chile: Universidad de Santiago, 2005. 
Del Pozo, Diego (ed.). Por la Humanidad Futura. Antología politica de Gabriela Mistral. Santiago, Chile: La Pollera, 2015.

\section{Critical Work}

Aldinger, Julio. "O ensaio biográfico e Gabriela Mistral: Sor Juana Inés de la Cruz". Hispanista 15. Disponible en: http://www.hispanista.com.br/revista/ soruana_julio_120.pdf.[Consultado el 10 de diciembre de 2015].

Barcia, Pedro Luis. "La prosa de Gabriela Mistral”, Gabriela Mistral en verso y prosa. Antología. Lima: RAE, (2010): LXIX-C.

Colmenares, Germán. Las convenciones contra la cultura. Ensayos sobre la historiografía hispanoamericana del siglo XIX. Santiago, Chile: Centro de investigaciones Diego Barros Arana, 2006.

Concha, Jaime. Gabriela Mistral. Santiago, Chile: Universidad Alberto Hurtado, 2015.

Cornejo Polar, Antonio. "Mestizaje, transculturación, heterogeneidad". In R. Kaliman (Coord.). Memorias de Jalla Tucumán 1995. Tucumán: Proyecto “Tucumán en los Andes. Vol. I. (1995): 267-270.

De Alba, Pedro. "Hispanismo e Indigenismo en Gabriela Mistral”, Anales de la Universidad de Chile 106 (1957): 79-80.

Figueroa, Lorena, Silva, Keiko y Patricia Vargas. Tierra, indio, mujer. Elpensamiento social de Gabriela Mistral. Santiago, Chile: Lom, 2000.

Quezada, Jaime. "Gabriela Mistral o la demócrata insufrible”. Gabriela Mistral. Escritos politicos. Santiago, Chile: Fondo de Cultura Económica (1994): 7-25.

--.----------. "Gabriela Mistral: ciudadana de las Américas”. Gabriela Mistral. Nuestra América. Santiago, Chile: Universidad de Santiago, (2005): 259-277.

Rojo, Grínor. "Nota sobre los nombres de América”, Atenea 483 (2001): 63-76.

Zermeño, Guillermo. "Del mestizo al mestizaje. Arqueología de un concepto”. En N. Böttcher, B. Hausberger y M. S. Hering Torres (Coord.), El peso de la sangre. Limpios, mestizos y nobles en el mundo hispánico. México, D. F.: El Colegio de México, (2011): 283-318. 